Ю. В. Харченко ${ }^{1}$, О. О. Дьомшина ${ }^{2}$, Т. Г. Андрейко О. О. Бондаренко ${ }^{1}$, К. О. Пісржиновська ${ }^{3}$, Г. О. Ушакова ${ }^{2}$, В. І. Жилюк ${ }^{1}$

\title{
Порівняльна характеристика
} гепатопротекторних ефектів фіксованої комбінації іпідакрину/фенібуту, пре/пробіотиків i S-аденозил-L-метіоніну за умов ізоніазид-рифампіцинового ураження печінки в щурів

\author{
${ }^{1}$ Державний заклад «Дніпропетровська медична академія Міністерства охорони \\ здоров'я України», м. Дніпро \\ ${ }^{2}$ Дніпровський національний університет імені Олеся Гончара, м. Дніпро \\ ЗЛундський університет, Швеція
}

Ключові слова: медикаментозний гепатит, S-аденозил-L-метіонін, пребіотики, пробіотики, іпідакрин, фенібут

Медикаментозно-індуковане ураження печінки (МІУП), викликане антитуберкульозною терапією, є одним з найпоширеніших ушкоджень печінки в багатьох країнах [1]. СYР2E1-опосередкований метаболізм ізоніазиду, а також рифампіцину 3 утворенням токсичних метаболітів чи вільних радикалів ймовірно є основним джерелом гепатотоксичності цих препаратів [1-4]. Причому сумісне застосування ізоніазиду та рифампіцину супроводжується ефектом взаємопотенціювання токсичних властивостей цих засобів, що збільшує ризик суттєвого ушкодження печінки [5]. Небезпеку становить безсимптомний «субклінічний» перебіг медикаментозного ураження печінки, за якого подальший прийом лікарських засобів спричинює розвиток тяжкого медикаментозного гепатиту, що супроводжується жовтяницею та печінковою енцефалопатією [6].

Не виключено, що вплив як ізоніазиду, так i рифампіцину на організм може бути опосередкований не лише їхньою гепатотоксичністю, але й здатністю викликати порушення балансу

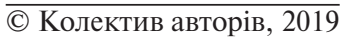

кишкової мікрофлори й мати довготривалі наслідки лікування найпоширенішої в світі інфекції людини [7-9]. 3 джерел літератури відомо, що хіміотерапія туберкульозу в цілому не порушує загальну різноманітність мікробіому, проте виснажує множинні імунологічно значимі коменсальні бактерії [7, 8]. Причому зрушення стану мікробіоти після проведеної терапії можуть зберігатися не менше ніж 1 рік [8].

Отже, можна передбачити, що комплекс змін в організмі, який спостерігається під впливом протитуберкульозних засобів, може сприяти розвитку гепато-ентеральної дисфункції. Причому обидва стани можуть негативно взаємно потенціювати один одного.

Завдяки інтенсивному розвитку фармакології сьогодні існуе можливість проводити якісну медикаментозну корекцію функції печінки, здійснювати заходи, направлені на захист її клітин, а також відновлювати стан мікробіоти кишечника. Однак і тепер достеменно не відомо, який вплив може чинити використання про/пребіотиків на прояви гепатотоксичності протитуберкульозних лікарських засобів. Водночас крім гепатотоксичності, яка може бути причиною розвитку енцефалопатії, для протитуберкульозних засобів, насамперед ізоніазиду, характерна 
наявність i прямих нейротоксичних ефектів, пов'язаних зі зниженням вмісту піридоксальфосфату. Наслідком цього може бути порушення синаптичної пластичності, а також прояви периферичної нейропатії. Значною мірою причиною цього є зниження вмісту в нервовій тканині нейромедіатора ГАМК [10]. Виходячи з цього, перспективним напрямом $\epsilon$ використання насамперед тих засобів, які здатні посилювати ГАМК-ергічну передачу в нервовій системі. I препаратом вибору за даних умов може бути фенібут. Слід зазначити, що відповідно до офіційної інструкції, використання фенібуту у високих дозах тривалий час може нести ризик розвитку гепатотоксичих ефектів цього препарату. Тому однією з задач нашого дослідження було встановити, яким чином відобразиться вплив фенібуту в дозі, яка не перевищувала умовно терапевтичну, на гепатотоксичність ізоніазиду та рифампіцину. Зважаючи на значну частоту розвитку полінейропатій у разі використання ізоніазиду, вивчали гепатотропні властивості фіксованої комбінації фенібуту з іпідакрином, який також здатний покращити синаптичну пластичність і проведення нервового імпульсу в центральній i периферичній нервовій системі.

Мета дослідження - вивчення впливу фіксованої комбінації іпідакрину/ фенібуту, пре/пробіотика (лактулоза/ йогурт) i S-аденозил-L-метіоніну на прояви гепатотоксичності в щурів за умов тривалого введення ізоніазиду та рифампіцину.

Матеріали та методи. Дослідження проведені на 40 білих щурах-самцях лінії Вістар масою 180-220 г, що утримувались за стандартних умов віварію Державного закладу "Дніпропетровська медична академія Міністерства охорони здоров'я України» (температура повітря: $(22 \pm 2){ }^{\circ} \mathrm{C}$, світло/темрява: 12/12 год). Усі експериментальні процедури здійснювали згідно 3 «Положенням про використання тварин у біомедичних дослідах» [11].

Експериментальну модель токсичного МІУП відтворювали шляхом повторних інтрагастральних введень ізоніазиду та рифампіцину в дозах 50 мг/кг i
86 мг/кг маси тіла протягом 28 діб з використанням Полісорбату LAUROPAN T/80 (Італія) і дистильованої води [2]. Тварин було розподілено на 5 груп (n = 8 у кожній). I - інтактна, II - контроль (МІУП). Щурам III групи протягом останніх 14 діб експерименту за 1 год до введення туберкулостатиків внутрішньом' язово вводили S-аденозил-L-метіонін ( «Гептрал®», Abbott Laboratories GmbH, S-ALM) у дозі 35 мг/кг. Тваринам IV групи у співставному режимі інтрагастрально вводили фіксовану комбінацію іпідакрину гідрохлориду/ фенібуту ( «огніфен ${ }^{\circledR}$ », Olainfarm, Латвія, Ip/Phe) у дозах 1/60 мг/кг, $\mathrm{V}$ група тварин інтрагастрально отримувала комбіновану терапію, що поєднувала пребіотик Лактулозу в дозі 2680 мг/кг («Нормазе ${ }^{\circledR}$, Delta Medical Promotions AG, Lac) i пробіотик, що містить 4 млрд активних клітин (КУО): Lactobacillus acidophilus, Lactobacillus rhamnosus, Streptococcus thermophilus, Lactobacillus delbrueckii subsp. Bulgaricus у дозі 1 КУО/кг («Йогурт», Pharmascience, Үо). Розрахунок доз проводили з урахуванням вищої терапевтичної дози для людини з використанням міжвидового коефіцієнта перерахунку доз людина/щури. Контрольним тваринам вводили аналогічний обсяг дистильованої води.

Через 24 год після останнього введення препаратів тварин виводили 3 експерименту, здійснювали забір крові, печінку зважували для розрахунку відносної маси (на 100 г) і гомогенізували. Цитозольну фракцію печінки отримували шляхом диференційного центрифугування в середовищі гомогенізації: 250 ммоль/л сахароза, 1 ммоль/л ЕДТА, 10 ммоль/л трис$\mathrm{HCl}, \mathrm{pH}$ 7,4 (0-3 $\left.{ }^{\circ} \mathrm{C}\right)$ [12].

Визначення активності аланінамінотрансферази (АлАТ, КФ 2.6.1.2) у сироватці крові проводили з використанням стандартного лабораторного тест-набору (ТОВ НВП «Філісіт-Діагностика», Україна) на біохімічному напівавтоматичному аналізаторі BS-3000M (Sinnowa, Китай).

Ступінь карбонільного стресу визначали спектрофотометрично в гомогенатах тканини печінки за показником окиснювальної модифікації білка шля- 
хом визначення кетонфенілгідразонів (КФГ) за реакцією взаємодії з 2,4-динітрофенілгідразином (2,4-ДНФГ) [13].

Показники енергетичного обміну оцінювали за вмістом лактату та пірувату в гомогенаті печінки. Концентрацію молочної кислоти визначали за ії здатністю утворювати оцтовий альдегід у кислому середовищі, який у разі взаємодії з гідрохіноном утворює сполуку червоно-коричневого кольору; пірувату - за інтенсивністю забарвлення комплексу 2,4-динітрофенілгідразону 3 піровиноградною кислотою в лужному середовищі [14].

Кількісний вміст білка S100b визначали за допомогою інгібіторного методу імуноферментного аналізу 3 використанням моноспецифічних антитіл до S100b (Abcam, Англія) і відповідного очищеного білка як стандарту (Abnovo, CША) [15]. Вміст S100b характеризували відношенням його кількості в пробі до кількості загального білка (ЗБ) у даному екстракті (мкг S100b /мг ЗБ), який визначали за методом Бредфорда [16]. Вимірювання оптичної густини здійснювали на мікропланшетному фотометрі «Anthos 2010» (Фінляндія) за довжини хвилі 492 нм.

Для світлової мікроскопії фрагменти печінки фіксували в $10 \%$ формаліні в забуференому фізіологічному розчині $(\mathrm{pH} 7,4)$ протягом 24 год за кімнатної температури. Надалі дослідні зразки зневоднювали у висхідних розчинах ізопропанолу, просвітлювали в ксилолі та заливали в парафін. Для гістологічного дослідження структурних змін виготовляли зрізи тканин товщиною 5 мкм. Дві серії зрізів фарбували гематоксиліном та еозином і ШИК-реакцією для виявлення складних вуглеводів. Усі гістологічні критерії оцінювали в дев'яти різних полях зору (FOV) для кожного зразка за збільшення $\times 400$.

Отриманий цифровий матеріал обробляли методом варіаційної статистики за допомогою програми статистичного аналізу StatPlus, AnalystSoft Inc. Bepсія 6 (http://www.analystsoft.com/ru/).

Результати та їх обговорення. Результати проведених досліджень свідчать, що тривале інтрагастральне введення ізоніазиду та рифампіцину супроводжується явищами гепатоцитолізу, про що свідчило зростання на $54,4 \%(\mathrm{p}<0,05)$ рівня індикативного ферменту АлАТ у крові контрольних тварин порівняно з інтактними щурами. Додатковим критерієм було й збільшення на $39,4 \%(\mathrm{p}<0,05)$ відносної маси печінки (рис. 1,2 ). Відбулося збільшення на 43,4 \% $(\mathrm{p}<0,05)$ вмісту карбонільних похідних, яке свідчило про посилення інтенсивності вільнорадикальних процесів у печінці дослідних тварин і розвиток «окисного стресу» (рис. 3). Водночас спостерігали

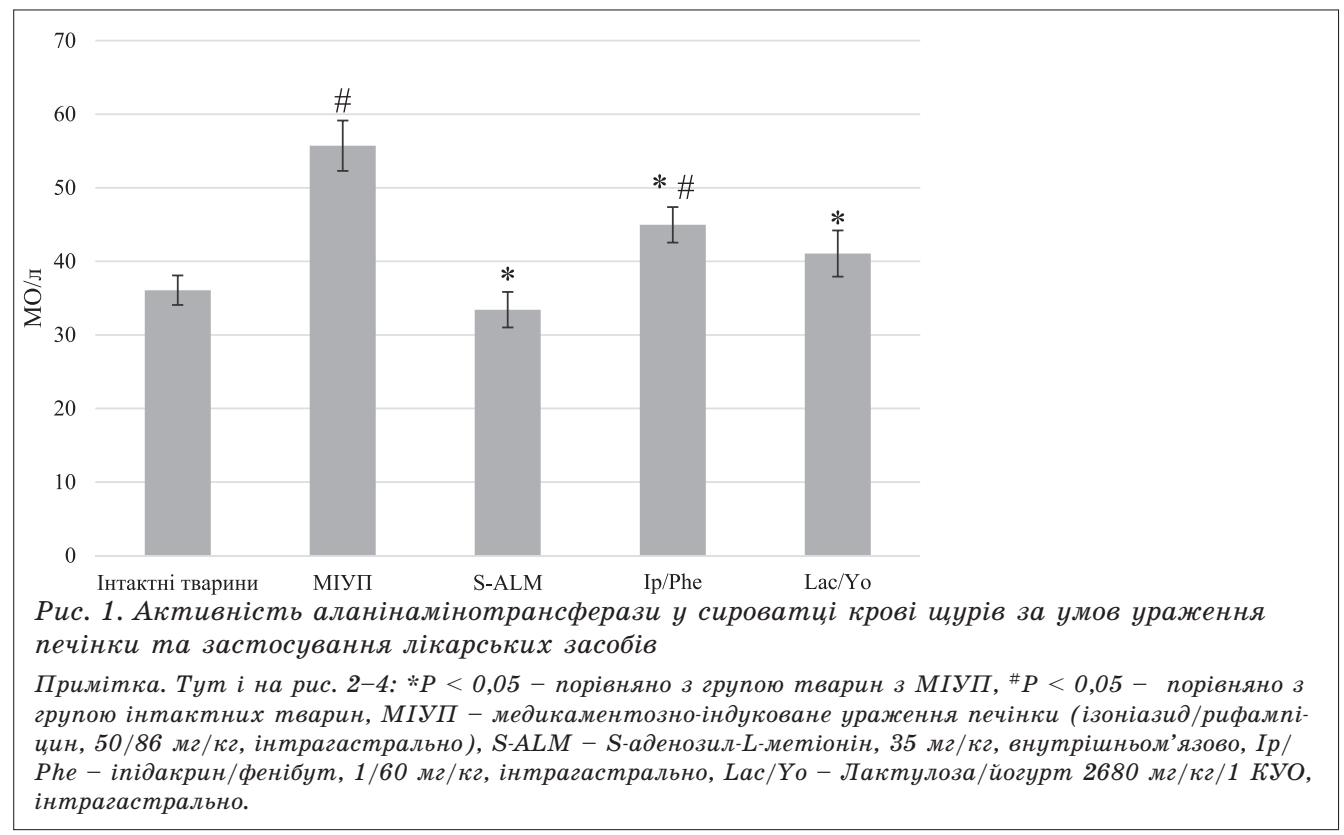

Фармакологія та лікарська токсикологія, Том 13, № 6/2019 

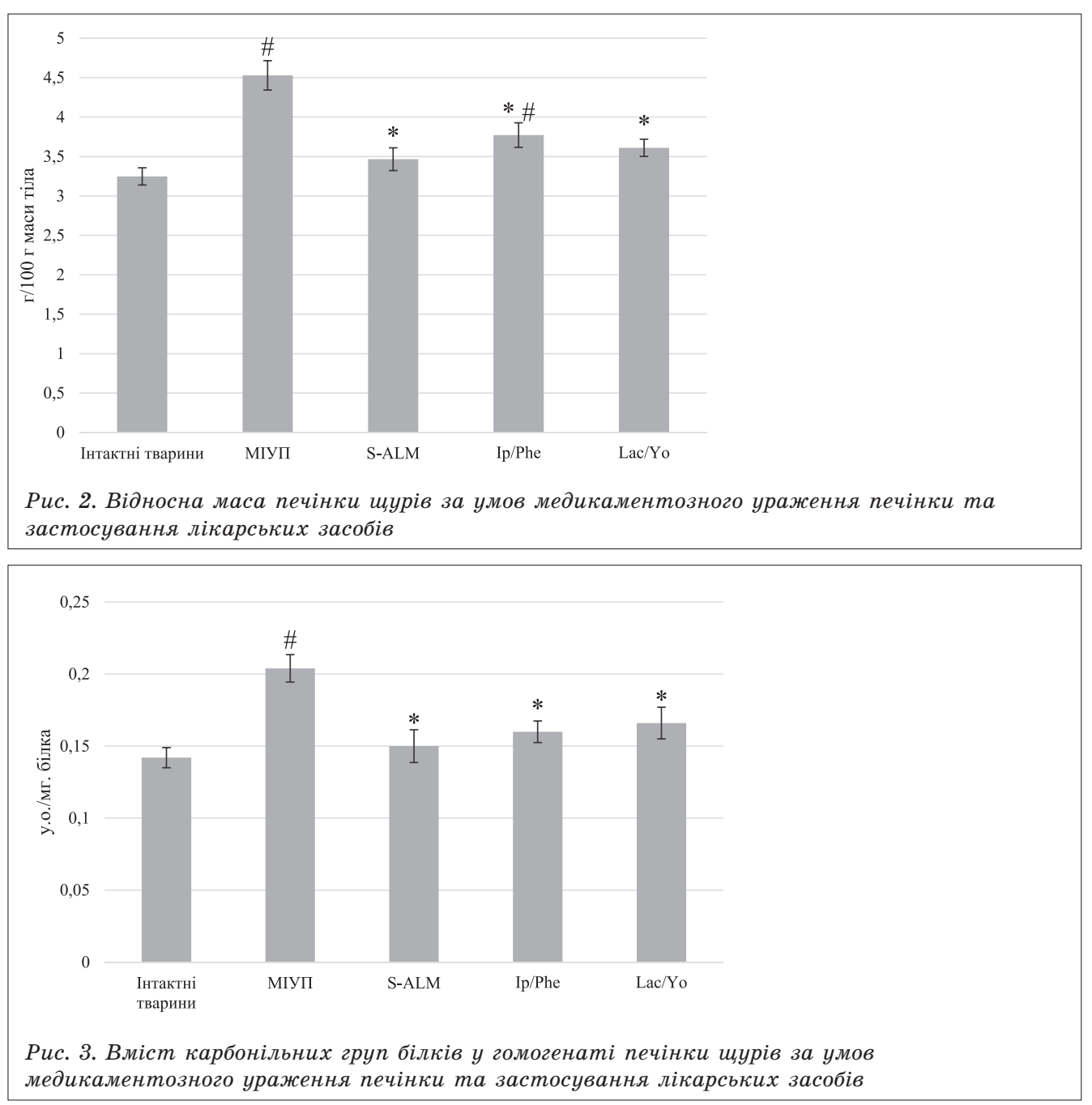

активацію анаеробного шляху метаболізму глюкози - гліколізу (таблиця), про що свідчило статистично значиме накопичення лактату та суттєве підвищення співвідношення лактату/пірувату. Так, у печінці щурів з МІУП рівень лактату був у 4,8 разу $(\mathrm{p}<0,05)$ вищим, пірувату - на $65 \%(\mathrm{p}<0,05)$ нижчим, а співвідношення лактат/ піруват збільшувалося в 13,6 разу порівняно з відповідними показниками групи інтактних тварин.

У ході експерименту також визначено, що токсичне ураження печінки ізоніазидом і рифампіцином характеризувалося зниженням на 44,4 \% $(\mathrm{p}<0,05)$ вмісту кальцій-зв'язувального білка S-100b (рис. 4).

Гістологічний аналіз досліджуваного матеріалу виявив, що в усіх зразках печінки щурів з МІУП спостерігалися стереотипні зміни, а саме: лімфогістіоцитарна інфільтрація перипортальних трактів - 10-20 клітин у полі зору (рис. 5) порівняно з тваринами I групи (інтактні), де значення цього показника були $<10$ (рис. 6 А, В), інтерстеційний набряк (простору Діссе), гідропічна дистрофія гепатоцитів.

За умов проведення експериментальної терапії були отримані наступні результати впливу лікарських засобів чи їхніх комбінацій на прояви гепатотоксичності за умов тривалого введення медикаментозних ксенобіотиків. Так, на тлі курсового внутрішньом'язового введення S-ALM у сироватці крові спостерігали статистично значиме на $28,8 \%(\mathrm{p}<0,05)$ зниження активності АлАТ, а також на $23,5 \%(\mathrm{p}<0,05)$ зменшення відносної маси печінки (рис. 1, 2). Крім цього, у разі викорис- 
Показники енергетичного обміну в печінці цурів за улов медикаментозного ураження печінки та застосування лікарських засобів $(M \pm m, n=8)$

\begin{tabular}{|l|c|c|c|}
\hline \multicolumn{1}{|c|}{ Група тварин } & $\begin{array}{c}\text { Лактат, мкмоль/мг } \\
\text { тканини }\end{array}$ & $\begin{array}{c}\text { Піруват, мкмоль/мг } \\
\text { тканини }\end{array}$ & Лактат/ піруват \\
\hline Інтактні щури & $2,04 \pm 0,19$ & $0,20 \pm 0,02$ & 10,2 \\
\hline МІУП & $9,73 \pm 0,84^{*}$ & $0,070 \pm 0,001^{\star}$ & 139 \\
\hline МІУП + S-ALM & $3,48 \pm 0,4^{*}, \#$ & $0,12 \pm 0,01^{*}, \#$ & 28,3 \\
\hline МІУП + Ір/Phe & $3,12 \pm 0,3^{*}, \#$ & $0,11 \pm 0,01^{*, \#}$ & 27,8 \\
\hline МІУП + Lac/Yo & $2,17 \pm 0,12^{\#}$ & $0,18 \pm 0,03^{\#}$ & 12,1 \\
\hline
\end{tabular}

Примітка. $* P<0,05$ порівняно з показником інтактних тварин, ${ }^{\#} P<0,05$ порівняно з показником тварин $з$ МІУП.

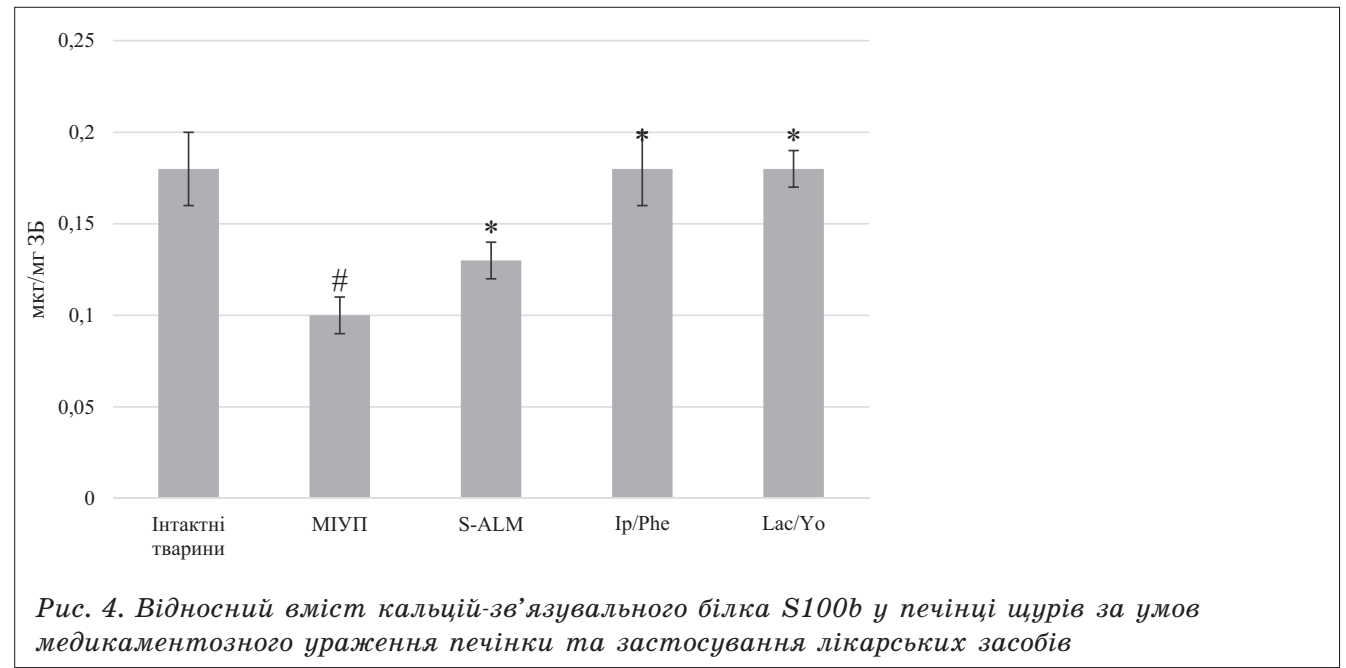

тання S-ALM відмічено зменшення на $16,1 \%(\mathrm{p}<0,05)$ вмісту карбонільних груп білків (рис. 3). Подібні зміни зафіксовані в разі використання фіксованої комбінації Ip/Phe. Так, активність АлАТ на 19,3\% (p < 0,05), а показник відносної маси печінки на $16,7 \%,(\mathrm{p}<0,05)$ були меншими порівняно $з$ тваринами з МІУП (рис. 1, 2). Водночас рівень КФГ у цих тварин знижувався на 21,5 \% (p < 0,05) (рис. 3$)$. У свою чергу, комбіноване введення пре/пробіотика також супроводжувалося зменшенням виразності явищ токсичного ураження печінки. Активність АлАТ, відносна маса печінки та вміст карбонільних похідних були відповідно на $26,3 \%(\mathrm{p}<0,05), 20,3 \%(\mathrm{p}<0,05)$ i $18,8 \%(\mathrm{p}<0,05)$ нижчими, ніж показники групи тварин з відтвореною в експерименті патологією печінки.

Водночас введення S-ALM призводило до зниження вмісту в тканині печінки тварин з МІУП рівнів лактату та збільшення вмісту пірувату - на 64,2\% $(\mathrm{p}<0,05)$ і $71,4 \%(\mathrm{p}<0,05)$ відповідно та зменшення співвідношення лактату/ пірувату (таблиця). Зміни показників цих ключових метаболічних маркерів у разі введення фіксованої комбінації іпідакрину/фенібуту за своїми значен-

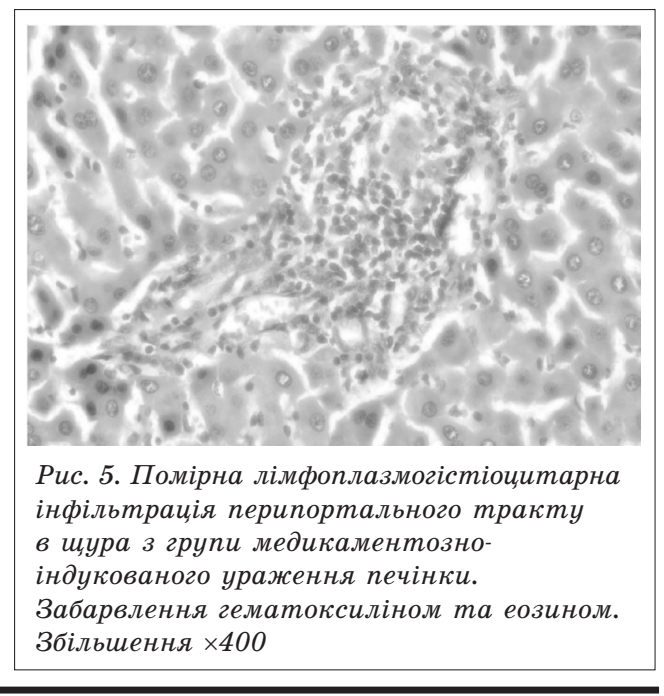




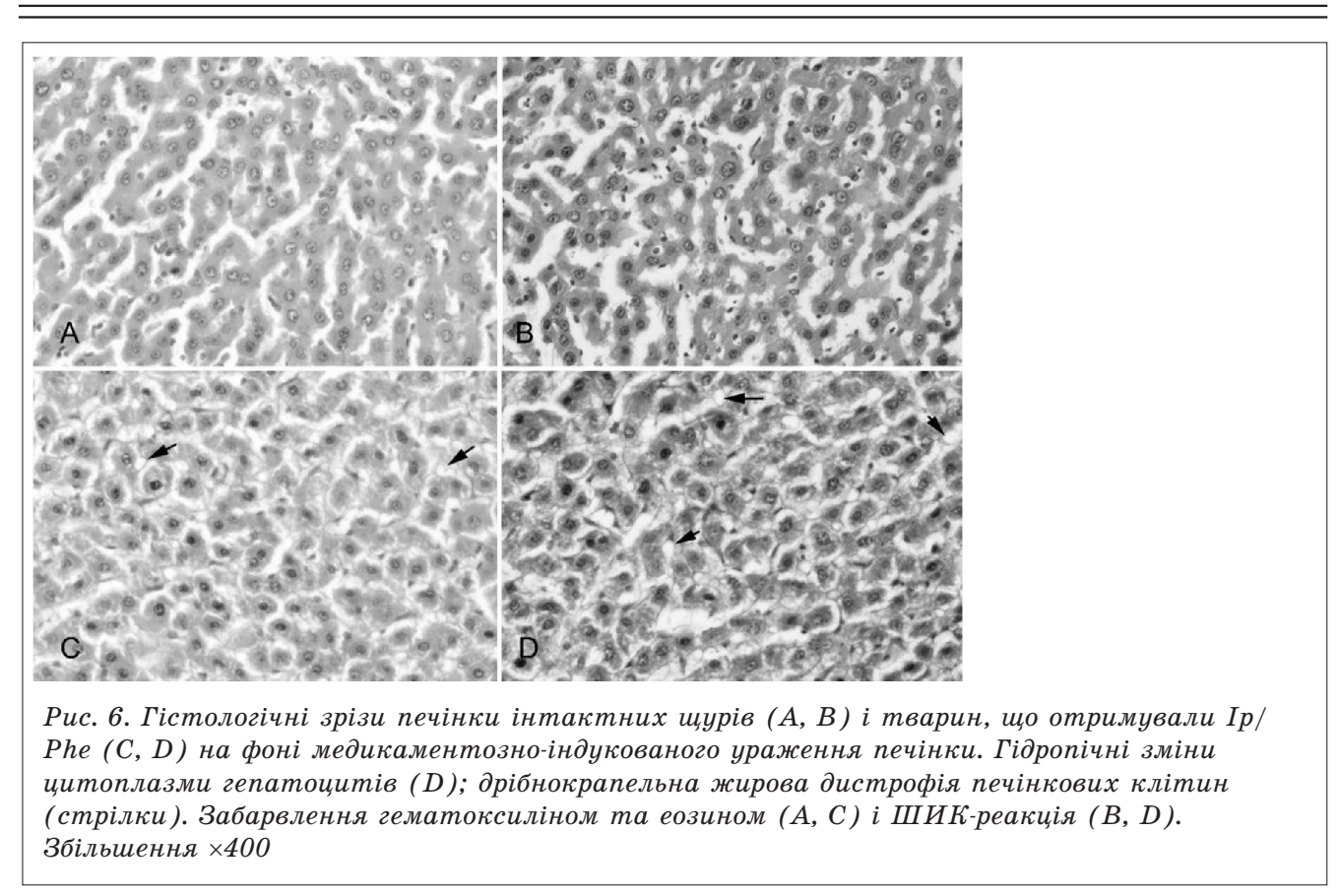

нями мало відрізнялися від групи S-ALM (таблиця). Водночас найбільший позитивний вплив на активність процесів гліколізу та утилізації надлишків лактату за умов тривалого введення ізоніазиду та рифампіцину спричиняли препарати, що відновлюють стан мікробіоценозу кишечника. За даних умов значення досліджуваних показників у цій групі практично не відрізнялися від даних, отриманих у тварин I групи.

Слід відмітити, що курсове введення використаних у дослідженні лікарських засобів також призводило до відновлення вмісту білка S-100b у тканині печінки за використання Ip/Phe та Lac / Үо у тварин з МІУП (рис. 4). Дещо меншими, однак у 1,3 разу статистично значимо більшими, ніж у групі тварин з МІУП за відповідних умов, були значення цього показника в разі використання S-ALM (рис. 4).

Патоморфологічні дослідження показали, що в тварин, які отримували експериментальну терапію S-ALM чи Ip/ Phe, зміни в печінковій тканині були однотипними. Виявлено жирову дистрофію (стеатоз) поодиноких гепатоцитів. Хоча інфільтрація перипортальних трактів мононуклеарами (лімфоцитами, макрофагами) мала доволі обмежений і в цілому незначний характер (<
10 клітин у полі зору), однак, гепатоцити цих тварин демонстрували виразну гідропічну дистрофію (набряк) у цитоплазмі (рис. 2 C, D).

Водночас у групі щурів, яким вводили пре/пробіотик, патоморфологічні характеристики тканини печінки майже не відрізнялися від таких у групі інтактних тварин і виявлялися незначною лімфогістіоцитарною інфільтрацією (< 10 клітин у полі зору) i набряком строми.

Отже, проведені біохімічні та патоморфологічні дослідження дозволили встановити розвиток значущих функціональних порушень, що розвиваються в печінці тварин за умов 28-денного інтрагастрального введення медикаментозних гепатотоксикантів - ізоніазиду та рифампіцину, які свідчать про розвиток токсичного ураження печінки. Відомо, що оксидативний стрес, який виникає внаслідок ураження гепатоцитів за вірусного, медикаментозного чи токсичного гепатиту, алкогольної чи неалкогольної жирової хвороби печінки, високий рівень оксиду азоту, прозапальних цитокінів призводять до зменшення активності метіонінаденозилтрансферази (MAT I/III) i, відповідно, біосинтезу ендогенних S-аденозил-L-метіоніну та глутатіону, які $€$ надзвичайно важливими компонентами 
антиоксидантного захисту клітини [17]. Слід зазначити, що гепатопротекторна терапія 3 використанням екзогенного S-ALM зменшує виразність явищ гепатотоксичності, які викликані тривалим застосуванням ізоніазиду та рифампіцину, і характеризується зменшенням проявів гепатоцитолізу, оксидативного стресу, покращанням метаболічних процесів у печінці. Отримані результати підтверджують фармакологічну активність цього препарату за ураження печінки. Цікавим $\epsilon$ факт, що використання комбінації іпідакрину/фенібуту також характеризувалося достатнім гепатопротекторним потенціалом, який за своїми характеристиками не поступався адеметіоніну. Слід зазначити, що в нашому дослідженні курсове використання фенібуту в складі комбінованого препарату в дозі, яка не перевищувала умовно терапевтичну, не потенціювало гепатотоксичність ізоніазиду та рифампіцину, а морфологічні зміни в печінці були тотожними тим, які спостерігалися в разі використання гепатопротектора адеметіоніну. Цілком імовірно, що гепатозахисний потенціал фіксованої комбінації забезпечений фармакологічними властивостями фенібуту. Згідно 3 даними, отриманими О. В. Мансимовою та співавт., фенібут характеризується здатністю стимулювати пластичні процеси в гепатоцитах і покращувати репаративні процеси в печінці за умов гострого токсичного ураження парацетамолом [18]. Найцікавіші результати отримані за курсового введення пре/пробіотика. За даних умов, значення показників метаболічного обміну, оксидативної напруги та морфологічні зміни в печінці найменше відрізнялися від групи інтактних тварин. Це підтверджує вплив стану кишкової мікрофлори на функції органів і систем організму, зокрема, печінки, а також актуальність включення про- та пребіотиків у терапію уражень печінки [19]. Ізоніазид i рифампіцин $\epsilon$ індукторами токсичного ураження гепатоцитів, а також протимікробними засобами, тривала терапія якими ініціює розвиток дисбіозу кишечника [7-9]. У кінцевому результаті ці про- цеси можуть спричиняти появу активного замкнутого кола в патогенезі дисфункції печінки за умов використання цих засобів. Виходячи з отриманих результатів, саме корекція мікрофлори кишечника $є$ найоптимальнішим напрямом відновлення функції печінки за їі ураження туберкулостатичними засобами, що підтверджується й результатами морфологічних досліджень [20].

3 іншого боку, важливими є дані щодо змін рівнів у тканині печінки нейроспецифічної ізоформи білка S100b, кислого кальцій-зв' язувального внутрішньоклітинного протеїну, що переважно зосереджений та секретується астроглією, а його основними функціями $є$ медіаторна й модуляторна регуляція міжклітинних відносин [21, 22]. Зменшення його рівня в печінці за умов введення ізоніазиду та рифампіцину може вказувати на порушення симпатичної та парасимпатичної регуляції цього органа, що впливає на гемодинаміку, секрецію та виділення жовчі, метаболізм вуглеводів i жирів [23]. Водночас цей маркер може бути й раннім індикатором стану печінкових нервових волокон у портальній зоні та репрезентувати ранні прояви уражень печінки, що передують розвитку цирозу [23]. Згідно з отриманими даними, тривале введення ізоніазиду та рифампіцину призводить до вірогідного зменшення вмісту білка S100b у тканині печінки. Водночас у всіх дослідних групах експериментальна терапія сприяла статистично значущому збільшенню цього білка в напрямку стабілізації. Причому найбільшою мірою відновлення значень цього маркера спостерігалося в тварин, які отримували комбіновану терапію - іпідакрин/фенібут чи лактулоза/йогурт. Цей факт може вказувати на те, що механізми захисту печінки цими засобами можуть бути опосередковані не лише покращанням метаболічних процесів чи пригніченням проявів оксидативного ураження, але й відновленням вегетативної нейрональної регуляції функції печінки. Однак визначення механізмів цього ефекту потребує подальших досліджень. 


\section{Висновки}

1. Тривале введення медикаментозних гепатотоксикантів - ізоніазиду та рифампіцину призводить до ушкодження печінки, яке проявляється гепатоцитолізом, розвитком оксидативного стресу, пригніченням метаболічних процесів і зниженням вмісту білка S100b.

2. S-аденозил-L-метіонін чи комбінації іпідакрин/фенібут і лактулоза/йогурт за повторних, протягом 14 діб, введень оптимізують процеси метаболізму глюкози, пригнічують окисну модифікацію білка та зменшують виразність явищ гепатоцитолізу за умов ізоніазид-рифампіцинового ураження печінки, що вказує на здатність цих препаратів зменшувати прояви гепатотоксичності туберкулостатиків.
3. Використання комбінацій іпідакрин/ фенібут чи лактулоза/йогурт призводить до збільшення вмісту білка $\mathrm{S} 100 \mathrm{~b}$ у печінці, що може свідчити про відновлення нейрональної регуляції функції цього органа.

4. Корекція стану мікробіоти кишечника лактулозою/йогуртом характеризується найбільшим захисним потенціалом щодо печінки порівняно 3 використанням комбінації іпідакрин/фенібут чи гепатопротектора $\mathrm{S}$-аденозил-L-метіонін і вказує на доцільність їі застосування вже на ранніх етапах терапії туберкулостатичними засобами як з метою попередження розвитку дисбіозу кишківника, так і для зменшення їхньої гепатотоксичності.

1. Protective effects of kaempferol on isoniazid- and rifampicin-induced hepatotoxicity. T. Y. Shih, T. H. Young, H. S. Lee et al. AAPS J. 2013. V. 15, № 3. P. 753-762.

2. Hepatoprotective effect of experimental polyvitamin composition under isoniazid and rifampicin dependent induction of cytochrome p-450 2e1. L. G. Berezhna, V. N. Kovalenko, A. M. Shayakhmetova et al. Modern problems of Toxicology. J. 2005. V. 48, № 3. P. 54-58.

3. Isoniazid metabolism and hepatotoxicity. Pengcheng Wang, Komal Pradhan, Xiao-bo Zhong and Xiaochao Ma. Acta Pharm. Sin. B. 2016. V. 6, № 5. P. 384-392.

4. Rozmaritsa N. O., Alexeeva I. M., Chekman I. S. Isoniazid-induced hepatotoxicity. Modern problems of toxicology. 2008. V. 68, № 4. P. 38-41.

5. Potentiating effect of rifampicin on methimazole induced hepatotoxicity in mice. Z. Hakim, A. Waheed, S. Bakhtiar et al. Pakistan Journal of Pharmaceutical Sciences (PJPS). 2018. V. 31, № 6. P. 2373-2377.

6. Quality of life in patients with minimal hepatic encephalopathy. L. Ridola, S. Nardelli, S. Gioia, O. Riggio. World J. Gastroenterol. 2018. V. 24, № 48. P. 5446-5453.

7. Longitudinal profiling reveals a persistent intestinal dysbiosis triggered by conventional anti-tuberculosis therapy. N. Sivaranjani, M. Mamoudou, Y. Wuxing et al. Microbiome. 2017. V. 71, № 5. P. 71. URL : https://microbiomejournal.biomedcentral.com/articles/10.1186/s40168-017-0286-2\#citeas.

8. Antibiotic treatment for Tuberculosis induces a profound dysbiosis of the microbiome that persists long after therapy is completed. M. F. Wipperman, D. W. Fitzgerald, M. A. J. Juste et al. Sci. Rep. 2017. V. 7. 10767. URL: https://www.nature.com/articles/s41598-017-10346-6\#citeas.

9. The Microbiome and Tuberculosis: Early Evidence for Cross Talk. S. Namasivayam, A. Sher, M. S. Glickman, M. F. Wipperman. mBio. 2018. V. 9, № 5. e01420-18. URL : https://www.ncbi.nlm. nih.gov/pmc/articles/PMC6143735/pdf/mBio.01420-18.pdf.

10. Тюлькова T. Е. Влияние пиридоксина и препаратов гидразида изоникотиновой кислоты на нервную систему при лечении туберкулеза. Туберкулез и болезни легких. 2018. Т. 96, № 11. C. 69-73.

11. Етика лікаря та права людини: положення про використання тварин у біомедичних дослідах. Експерим. та клін. фізіологія і біохімія. 2003. № 2 (22). С. 108-109.

12. Isolation of mitochondria-associated membranes and mitochondria from animal tissues and cells. M. R. Wieckowski, C. Giorgi, M. Lebiedzinska et al. Nature Protocols. 2009. V 4, № 11. P. 1582-1590.

13. Окислительная модификация белков сыворотки крови человека, метод ее определения. Е. Е. Дубинина, С. О. Бурмистров, Д. А. Ходов и др. Вопр. мед. химии. 1995. Т. 41, № 1. C. 24-26.

14. Ветеринарна клінічна біохімія: навч. посібник. Д. О. Мельничук, В. А. Грищенко, В. А. Томчук та ін. 2 вид., перероб. Київ : НУБіП України, 2014. 456 с.

15. Нго Т. Т., Ленхофф Г. М., Яклич А. Иммуноферментный анализ. Москва : Мир, 1988. 444 с. 
16. Bradford M. Rapid and sensitive methods for the quantitation of microgram quantities of protein utilizing the principle of protein-dye binding. Anal. Biochem. 1985. № 72. P. 248-254.

17. Звягинцева Т.Д., Чернобай А. И., Глущенко С. В. Хронические заболевания печени и нарушение синтеза S-аденозил-L-метионина. Сучасна гастроентерологія. 2014. № 3 (77). С. 80-87.

18. Влияние фенибута, пантогама и пикамилона на процессы репаративной регенерации гепатоцитов в условии их токсического поражения парацетамолом и чХУ. О. В. Мансимова, Е. Н. Конопля, С. С. Беляева, Е. В. Огнещикова. Успехи современного естествознания. 2003. № 10. C. 78.

19. Park W. Gut microbiomes and their metabolites shape human and animal health. J. Microbial. 2018. V. 56. P. $151-153$.

20. Gut-Liver Axis: How Do Gut Bacteria Influence the Liver? P. C. Konturek, I. A. Harsch, K. Konturek et al. Med. Sci. 2018. V. 6, № 3, 79. URL: https://doi.org/10.3390/medsci6030079.

21. S100B expression in and effects on microglia. C. Adami, G. Sorci, E. Blasi et al. Glia. 2001. V. 33. P. 131-142.

22. Ziablitsev S. V., Yuzkiv Ya. S., Dyadyk O. O. Dynamics of neurospecific proteins content and their formation in experimental brain injury. Pathologia. 2016. № 1 (36). P. 49-53.

23. Decreased S100B expression in chronic liver diseases. S. J. Baik, T. H. Kim, K. Yoo et al. J. Intern. Med. 2017. V. 32. P. 269-276.

\section{Ю. В. Харченко, О. О. Демшина, Т. Г. Андрейко, О. О. Бондаренко, К. О. Пієржиновська, Г. О. Ушакова, В. І. Жилюк Порівняльна характеристика гепатопротекторних ефектів фіксованої кобінації іпідакрину/фенібуту, пре/пробіотиків і S-аденозил-L-метіоніну за умов ізоніазид-рифампіцинового ураження печінки в щурів}

Мета дослідження - вивчення впливу фіксованої комбінації іпідакрину/фенібуту, пре/пробіотика та S-аденозил-L-метіоніну на прояви гепатотоксичності в щурів за умов тривалого введення ізоніазиду та рифампіцину.

Дослідження проводили на 40 білих щурах-самцях лінії Wistar масою 180-220 г. Експериментальну модель токсичного медикаментозного ураження печінки (МІУП) відтворювали шляхом повторних внутрішньошлункових введень ізоніазиду та рифампіцину в дозах 50 мг/кг і 86 мг/кг маси тіла протягом 28 діб. Тварин було розподілено на 5 груп ( $\mathrm{n}=8$ у кожній). I - інтактна, II - контроль (МІУП). Щурам III групи протягом останніх 14 діб експерименту за 1 год до введення туберкулостатиків внутрішньом'язово вводили S-аденозил-L-метіонін у дозі 35 мг/кг. Тваринам IV групи в співставному режимі інтрагастрально вводили фіксовану комбінацію іпідакрину гідрохлориду/ фенібуту в дозах 1/60 мг/кг, V група шлунково отримувала комбіновану терапію, що поєднувала пребіотик Лактулозу в дозі 2680 мг/кг та пробіотик, що містить 4 млрд активних клітин (КУО): Lactobacillus acidophilus, Lactobacillus rhamnosus, Streptococcus thermophilus, Lactobacillus delbrueckii subsp. Bulgaricus у дозі 1 КУО/кг. Гепатопротекторні властивості оцінювали за показниками відносної маси печінки (на 100 г), активністю аланінамінотрансферази в сироватці крові, показниками окисної модифікації білка, метаболічного обміну (вміст лактату та пірувату), кількісного вмісту білка S100b та за результатами гістологічного дослідження тканини печінки.

Результати експериментів свідчать про те, що тривале введення медикаментозних гепатотоксикантів - ізоніазиду та рифампіцину призводило до ушкодження печінки, яке проявлялося явищами гепатоцитолізу, розвитком оксидативного стресу, пригніченням метаболічних процесів і зниженням рівня білка S100b. У свою чергу, S-аденозил-L-метіонін чи комбінації іпідакрин/ фенібут і лактулоза/йогурт за повторних, протягом 14 діб, введень сприяли значній оптимізації процесів метаболізму глюкози, пригнічували окисну модифікацію білка та зменшували виразність явищ гепатоцитолізу за умов ізоніазид-рифампіцинового ураження печінки. Причому, використання комбінацій іпідакрин/фенібут чи лактулоза/йогурт призводило до відновлення вмісту цитозольної фракції білка S-100b у тканині печінки в тварин з МІУП. У дещо меншому вираженні, однак у 1,3 разу статистично значимо більшими, ніж у групі тварин контролю за відповідних умов були значення цього показника в разі використання S-аденозил-L-метіоніну. Слід зазначити, що корекція стану мікробіоти кишечника лактулозою/йогуртом характеризується найбільшим захисним потенціалом відносно печінки порівняно з використанням комбінації іпідакрин/фенібут чи гепатопротектора - S-аденозил-L-метіоніну.

Отримані дані експериментально обґрунтовують доцільність відновлення біоценозу кишечника шляхом використання пре/пробіотиків з метою попередження чи комплексного лікування розладів печінки, що виникають внаслідок тривалого використання туберкулостатичної терапії.

Ключові слова: медикаментозний гепатит, S-аденозил-L-метіонін, пребіотики, пробіотики, іпідакрин, фенібут 
Ю. В. Харченко, О. А. Демшина, Т. Г. Андрейко, А. А. Бондаренко,

Е. А. Пиержиновская, Г. А. Ушакова, В. И. Жилюк

Сравнительная характеристика гепатопротекторных эффектов

фиксированной комбинации ипидакрина/фенибута, пре/пробиотиков

и S-аденозил-L-метионина в условиях изониазид-рифампицинового поражения печени у крыс

Цель исследования - изучение влияния фиксированной комбинации ипидакрина/фенибута, пре/пробиотиков и S-аденозил-L-метионина на проявления гепатотоксичности у крыс в условиях длительного введения изониазида и рифампицина.

Исследования проводили на 40 белых крысах-самцах линии Wistar массой 180-220 г. Экспериментальную модель токсического медикаментозного поражения печени (МИПП) воспроизводили путем повторных внутрижелудочных введений изониазида и рифампицина в дозе 50 мг/кг и 86 мг/кг массы тела в течение 28 сут. Животные были разделены на 5 групп (n = 8 в каждой). I интактная, II - контроль (МИПП). Крысам III группы в течение последних 14 сут эксперимента за 1 ч до введения туберкулостатиков внутримышечно вводили S-аденозил-L-метионин в дозе 35 мг/кг. Животным IV группы в сопоставимом режиме интрагастрально вводили фиксированную комбинацию ипидакрина гидрохлорида/ фенибута в дозах 1/60 мг/кг, V группа внутрижелудочно получала пребиотик лактулозу в дозе 2680 мг/кг и пробиотик, содержащий 4 млрд активных клеток (KOE): Lactobacillus acidophilus, Lactobacillus rhamnosus, Streptococcus thermophilus, Lactobacillus delbrueckii subsp. Bulgaricus в дозе $1 \mathrm{KOE} /$ кг. Гепатопротекторные свойства оценивали по показателям относительной массы печени (на 100 г), активности аланинаминотрансферазы в сыворотке крови, показателям окислительной модификации белка, метаболического обмена по содержанию лактата и пирувата, количественному содержанию белка S100b и по результатам гистологического исследования ткани печени.

Результаты экспериментов свидетельствуют о том, что длительное введение изониазида и рифампицина приводило к повреждению печени, которое проявлялось явлениями гепатоцитолиза, развитием оксидативного стресса, угнетением метаболических процессов и снижением уровня белка S100b. B свою очередь, S-аденозил-L-метионин или комбинации ипидакрина/Фенибута и лактулозы/йогурта при повторных введениях, в течение 14 суток, в значительной степени улучшали процессы метаболизма глюкозы, подавляли окислительную модификацию белка и уменьшали выраженность явлений гепатоцитолиза в условиях изониазид-рифампицинового поражения печени. Причем использование комбинаций ипидакрина/фенибута или лактулозы/йогурта приводило к восстановлению содержания цитозольной фракции белка S100b в ткани печени у животных c МИПП. В несколько меньшей степени, в 1,3 раза, однако статистически значимо больше, чем в группе животных с МИПП, было значение этого показателя при использовании S-аденозил-Lметионина. Следует отметить, что коррекция состояния микробиоты кишечника лактулозой/йогуртом имеет наибольший гепатопротективный потенциал по сравнению с использованием комбинации ипидакрина/фенибута или гепатопротектора - S-аденозил-L-метионина.

Полученные данные экспериментально обосновывают целесообразность восстановления биоценоза кишечника путем использования пре/пробиотиков с целью предупреждения или комплексного лечения пораженной печени, возникающих вследствие длительного использования туберкулостатической терапии.

Ключевые слова: медикаментозный гепатит, S-аденозил-L-метионин, пребиотики, пробиотики, ипидакрин, фенибут

\section{Yu. V. Kharchenko, O. A. Dyomshina, T. G. Andreiko, A. A. Bondarenko, K. A. Pierzhinovska, G. A. Ushakova, V. I. Zhilyuk Comparative characteristic of hepatoprotective effects of fixed combination of ipidacrin/penibute, pre/probiotics and S-adenosyl-L-methionine in conditions of isoniazid-rifampicin liver injury in rats}

The aim of the study was to evaluate the effects of the fixed combination of ipidacrine/phenibut, pre/ probiotic and S-adenosyl-L-methionine on the manifestations of hepatotoxicity in rats under long-term administration of isoniazid and rifampicin.

The studies were carried out on 40 white Wistar male rats weighing 180-220 g. The experimental model of toxic drug induced liver injury (DILI) was reproduced by repeated intragastric administration of isoniazid and rifampicin at a dose of $50 \mathrm{mg} / \mathrm{kg}$ and $86 \mathrm{mg} / \mathrm{kg}$ of body weight for 28 days. Animals were divided into 5 groups ( $n=8$ in each). I - intact, II - control (DILI). During the last 14 days of the experiment, rats of group III were injected intramuscularly with S-adenosyl-L-methionine at a dose of $35 \mathrm{mg} / \mathrm{kg}$. For animals of group IV, a fixed combination of ipidacrine hydrochloride/phenibut was administered at a comparable intragastric regimen at doses of $1 / 60 \mathrm{mg} / \mathrm{kg}$, and group $V$ intragastrically received therapy that combines the prebiotic lactulose at a dose of $2680 \mathrm{mg} / \mathrm{kg}$ and a probiotic containing 4 billion active cells (CFU): Lactobacillus acidophilus, Lactobacillus rhamnosus, Streptococcus thermophilus, Lactobacillus delbrueckii subsp. 
Bulgaricus at a dose of $1 \mathrm{CFU} / \mathrm{kg}$. Hepatoprotective properties were assessed by indicators of the relative mass of the liver (per $100 \mathrm{~g}$ ), activity of alanine aminotransferase in the blood serum, indicators of the oxidative modification of the protein, metabolic (the content of lactate and pyruvate), content of protein S100b and by histological studies of liver tissue.

The experimental results indicate that prolonged administration of drug hepatotoxicants, isoniazid and rifampicin, led to liver injury, which was manifested by hepatocytolysis, the development of oxidative stress, inhibition of metabolic processes and a decrease in S100b protein level. In turn, S-adenosyl-Lmethionine, or combinations of ipidacrine/phenibut and lactulose/yogurt after repeated administrations within 14 days, significantly optimized the processes of glucose metabolism, suppressed the oxidative modification of the protein and reduced the severity of hepatocytolysis under isoniazid rifampicin liver injury. Moreover, the use of combinations of ipidacrine/phenibut or yogurt/lactulose led to the restoration of the content of S100b protein in the cytosolic fraction in the liver tissue in animals with DILI. The value of this indicator was statistically significant 1,3 times greater when using S-adenosyl-L-methionine as compared with the group of animals with DILI. It should be noted that correction of the intestinal microbiota by lactulose/yogurt has the greatest hepatoprotective potential then the combination of ipidacrine/phenibut or hepatoprotector S-adenosyl-L-methionine.

The data obtained experimentally substantiate the feasibility of restoring the intestinal biocenosis by using pre/probiotics in order to prevent or complex treatment of liver disorders resulting from prolonged tuberculostatic therapy.

Key words: drug-induced hepatitis, S-adenosyl-L-methionine, prebiotics, probiotics, ipidacrine, phenibut

Прийнята до друку: 17 грудня 2019 р.

Контактна особа: Жилюк Володимир Іванович, доктор медичних наук, професор, кафедра фармакології і клінічної фармакології, ДЗ «Дніпропетровська медична академія МОЗУ», буд. 9, вул. В. Вернадського, м. Дніпро, 49044. Тел.: + 3805671355 53. Електронна пошта: zhylyuk@ua.fm 